\title{
Towards Heat-stable Oxytocin Formulations: Analysis of Degradation Kinetics and Identification of Degradation Products
}

\author{
Andrea Hawe, ${ }^{1}$ Robert Poole, ${ }^{1}$ Stefan Romeijn, ${ }^{1}$ Piotr Kasper, ${ }^{2}$ Rob van der Heijden, ${ }^{2}$ and Wim Jiskoot ${ }^{1,3}$
}

Received February 16, 2009; accepted March 16, 2009; published online April 3, 2009

\begin{abstract}
Purpose. To investigate degradation kinetics of oxytocin as a function of temperature and $\mathrm{pH}$, and identify the degradation products.

Materials and Methods. Accelerated degradation of oxytocin formulated at $\mathrm{pH} 2.0,4.5,7.0$ and 9.0 was performed at $40,55,70$ and $80^{\circ} \mathrm{C}$. Degradation rate constants were determined from RP-HPLC data. Formulations were characterized by HP-SEC, UV absorption and fluorescence spectroscopy. Degradation products were identified by ESI-MS/MS.

Results. The loss of intact oxytocin in RP-HPLC was pH- and temperature-dependent and followed (pseudo) first order kinetics. Degradation was fastest at $\mathrm{pH} 9.0$, followed by $\mathrm{pH} 7.0, \mathrm{pH} 2.0$ and $\mathrm{pH} 4.5$. The Arrhenius equation proved suitable to describe the kinetics, with the highest activation energy $\left(116.3 \mathrm{~kJ} / \mathrm{mol}\right.$ ) being found for $\mathrm{pH} 4.5$ formulations. At $\mathrm{pH} 2.0$ deamidation of $\mathrm{Gln}^{4}, \mathrm{Asn}^{5}$, and $\mathrm{Gly}^{9}-\mathrm{NH}_{2}$, as well as combinations thereof were found. At $\mathrm{pH} 4.5,7.0$ and 9.0, the formation of tri- and tetrasulfidecontaining oxytocin as well as different types of disulfide and dityrosine-linked dimers were found to occur. Beta-elimination and larger aggregates were also observed. At $\mathrm{pH}$ 9.0, mono-deamidation of Gln ${ }^{4}$, $\mathrm{Asn}^{5}$, and $\mathrm{Gly}^{9}-\mathrm{NH}_{2}$ additionally occurred.

Conclusions. Multiple degradation products of oxytocin have been identified unequivocally, including various deamidated species, intramolecular oligosulfides and covalent aggregates. The strongly $\mathrm{pH}$ dependent degradation can be described by the Arrhenius equation.
\end{abstract}

KEY WORDS: aggregation; Arrhenius kinetics; degradation; mass spectrometry; oxytocin.

\section{INTRODUCTION}

Oxytocin is a nonapeptidic hormone that is released from the posterior lobe of the pituitary gland of the hypothalamus. Therapeutically, it is used to induce or stimulate labor (1) and to prevent post-partum hemorrhage, which is a major cause of birth related maternal deaths in developing countries (2). In 1993 and 1994, the World Health Organization (WHO) supported a number of studies which demonstrated that oxytocin loses potency in field conditions, in particular in tropical climates $(3,4)$. Prompted by the WHO, a program was initiated recently by Top Institute Pharma (The Netherlands) entitled: Hot medicines-breaking the cold chain requirement for polypeptide-based priority medicines. The principal aim of this project is the rapid development of heat-stable oxytocin formulations in addition to several other peptide/protein-based priority medicines for

\footnotetext{
${ }^{1}$ Division of Drug Delivery Technology, Leiden/Amsterdam Center for Drug Research (LACDR), Leiden University, P.O. Box 9502, 2300 RA Leiden, The Netherlands.

${ }^{2}$ Division of Analytical Biosciences, Leiden/Amsterdam Center for Drug Research (LACDR), Leiden University, P.O. Box 9502, 2300 RA Leiden, The Netherlands.

${ }^{3}$ To whom correspondence should be addressed. (e-mail: w.jiskoot@ lacdr.leidenuniv.nl)
}

diseases including hepatitis B, diabetes and influenza. Integral to this work is the development of new analytical methods.

In order to be able to apply a scientific and intelligent approach to formulation development, a thorough knowledge of drug stability and degradation pathways is essential. Currently, there are only limited data available on oxytocin degradation and stability, despite oxytocin being a wellknown and extensively studied peptide hormone. Almost 30 years ago, it was shown by Nachtmann et al. (1981) that oxytocin is most stable between $\mathrm{pH} 3$ and 5, but only limiting data on degradation kinetics were given (5). In the following years, no relevant publications on degradation kinetics and pathways of oxytocin were published.

Because of the role oxytocin plays in the function of the central nervous system, research on its clinical application to treat anxiety- and depression-related diseases, as well as several neuropsychiatric disorders, including autism, obsessivecompulsive disorder, eating disorders and addiction is ongoing $(6,7)$. These new fields of application might also require new and innovative oxytocin formulations.

Oxytocin consists of a six amino acid ring $\left(\mathrm{Cys}^{1}, \mathrm{Tyr}^{2}\right.$ $\left.\mathrm{Ile}^{3}, \mathrm{Gln}^{4}, \mathrm{Asn}^{5}, \mathrm{Cys}^{6}\right)$ and a tail of three amino acids (Pro ${ }^{7}$, Leu $\left.{ }^{8}, \mathrm{Gly}^{9}-\mathrm{NH}_{2}\right) . \mathrm{Asn}^{5}$ and $\mathrm{Tyr}^{2}$ are the key moieties required for proper function at the active site of the uterine receptor and $\mathrm{Ile}^{3}, \mathrm{Gln}^{4}, \mathrm{Pro}^{7}$ and $\mathrm{Leu}^{8}$ are important for receptor binding (8). Any changes in the structure caused by chemical or physical instabilities can lead to loss of affinity to 
the receptor and/or altered biological activity. From an inspection of the amino acid sequence and chemical structure of oxytocin several sites are evident, which could be susceptible to degradation via deamidation, oxidation or thiol exchange. Gln ${ }^{4}$ and $\operatorname{Asn}^{5}$ within the macrocycle and the amidated C-terminal amino acid Gly ${ }^{9}$-amide are predisposed to deamidation. Under acidic conditions deamidation occurs mainly via acid catalyzed hydrolysis, i.e. $\mathrm{RCONH}_{2} \Rightarrow \mathrm{RCOOH}$ (9). Hydrolysis at low $\mathrm{pH}$ can also cause fragmentation. Under neutral and alkaline conditions, deamidation proceeds via the formation of cyclic imide intermediates (9-11). Tyr ${ }^{2}$ and Cys ${ }^{1,6}$ are susceptible to oxidation, activated for example by the presence of oxygen, light and/or metal ions. A further consideration for oxytocin is the stability of its $\mathrm{Cys}^{1}-\mathrm{Cys}^{6}$ disulfide bridge with respect to thiol exchange. At neutral and alkaline conditions this occurs via nucleophilic attack of free thiolate on one of the sulfur atoms within the disulfide bridge. At low $\mathrm{pH}$ the disulfide exchange progresses via a sulfenium cation, formed following protonation of the disulfide bridge $(9,12)$. In either case disulfide exchange can result in dimerization and progressive aggregation. Surprisingly, there is no detailed information about oxytocin degradation in therapeutic formulations available in the literature; this provoked us to undertake the study presented herein.

Our first objective was to analyze the kinetics of oxytocin degradation as a function of $\mathrm{pH}$ and temperature, an important step towards being able to predict the long-term stability of oxytocin at relevant storage temperatures. The second aim was to identify the degradation products and obtain insights into the degradation pathways, which would facilitate the rational design of heat-stable oxytocin formulations. In order to be able to identify and separate the various degradation products an optimized gradient RP-HPLC method was developed, based on the European Pharmacopoeia (13) and on the isocratic method described by Chaibva and Walker (14). In combination with high-resolution mass spectrometry, this enabled the identification of the main degradation products and provided mechanistic insight into the pathways leading to oxytocin degradation.

\section{MATERIALS AND METHODS}

\section{Materials}

Oxytocin acetate powder (Diosynth, Oss, The Netherlands) was dissolved in $50 \mathrm{mM}$ phosphate buffer $\mathrm{pH}$ 2.0, 4.5, 7.0 and 9.0. The exact concentration was determined by UV absorption spectroscopy, using an extinction coefficient at $280 \mathrm{~nm}$ of $1.52 \mathrm{ml} \mathrm{mg}^{-1} \mathrm{~cm}^{-1}$ based on Gill and Hippel (15). The formulation buffers were prepared at a concentration of $50 \mathrm{mM}$ using $\mathrm{NaH}_{2} \mathrm{PO}_{4} * 2 \mathrm{H}_{2} \mathrm{O}$ (Fluka, Zwijndrecht, The Netherlands), $\mathrm{Na}_{2} \mathrm{HPO}_{4} * 2 \mathrm{H}_{2} \mathrm{O}$ (Fluka, Zwijndrecht, The Netherlands) and ortho-phosphoric acid (Merck, Amsterdam, The Netherlands). All buffers were filtered through $0.2 \mu \mathrm{m}$ pore PES-filters (Millipore, Amsterdam, The Netherlands). For HPLC analytics, HPLC grade acetonitrile (ACN) and formic acid were used.

\section{Accelerated Stability Study of Oxytocin}

Oxytocin was formulated at a concentration of $0.1 \mathrm{mg} / \mathrm{ml}$ in $50 \mathrm{mM}$ phosphate at each of $\mathrm{pH} 2.0,4.5,7.0$ and 9.0. About
$9 \mathrm{ml}$ of each formulation were stored in 10R glass type I vials either at $40^{\circ} \mathrm{C}$ in a stove or at $55^{\circ} \mathrm{C}, 70^{\circ} \mathrm{C}$ or $80^{\circ} \mathrm{C}$ in water baths of constant temperature. To study the concentration dependency of oxytocin degradation, control experiments at $70^{\circ} \mathrm{C}$ were performed for all $\mathrm{pH}$ conditions at oxytocin concentrations of $0.02,0.1$ and $0.5 \mathrm{mg} / \mathrm{ml}$. The extent of degradation in each case was quantified by monitoring the disappearance of the main peak by RP-HPLC corresponding to oxytocin. During the stability studies the $\mathrm{pH}$ values of the formulations were controlled. They remained within $\pm 0.1 \mathrm{pH}$ units for $\mathrm{pH}$ 2.0, 7.0 and 9.0 formulations, and within $\pm 0.2 \mathrm{pH}$ units for $\mathrm{pH} 4.5$ formulations.

\section{UV Absorption Spectroscopy}

UV spectroscopy was performed with an Agilent 8453 UV/VIS spectrometer (Agilent, Waldbronn, Germany). Two $\mathrm{ml}$ of the oxytocin solutions were measured in quartz cuvettes with a path length of $10 \mathrm{~mm}$ and the particular buffer spectrum subtracted. Spectra were recorded from 240 to $340 \mathrm{~nm}$.

\section{Fluorescence Spectroscopy}

Steady state fluorescence spectra were measured with an FS920 fluorescence spectrometer (Edinburgh Instruments, Edinburgh, Scotland) in 96-well plates. To detect the formation of dityrosine, the undiluted formulations were measured using an excitation wavelength of $340 \mathrm{~nm}$, emission and excitation slits of $5 \mathrm{~nm}$, a dwell time of $0.5 \mathrm{~s}$, steps of $0.5 \mathrm{~nm}$ and a cumulative addition of two scans for each spectrum. The spectra were corrected by subtracting the buffer spectra, measured under the same conditions.

\section{Reversed Phase High Pressure Liquid Chromatography (RP-HPLC)}

RP-HPLC was performed using an Alltima C18 RPcolumn, $5 \mu \mathrm{m}$ particle size, inner diameter of $4.6 \mathrm{~mm}$ and length of $150 \mathrm{~mm}$ (Alltech, Ridderkerk, Netherlands), a Waters 600 controller with gradient pump, a Waters 717 autosampler, a Waters 2487 UV detector and helium sparge equipment (Waters, Milford Massachusetts, USA). Twenty $\mu 1$ of the samples were injected and the measurements were performed at a flow rate of $1.0 \mathrm{ml} / \mathrm{min}$ and $\mathrm{UV}$ detection at $220 \mathrm{~nm}$ and $280 \mathrm{~nm}$. Gradient elution with $15 \%(v / v) \mathrm{ACN}$ in $65 \mathrm{mM}$ phosphate buffer $\mathrm{pH} 5.0$ as solvent $\mathrm{A}$ and $60 \%(\mathrm{v} / \mathrm{v})$ acetonitrile in $65 \mathrm{mM}$ phosphate buffer $\mathrm{pH} 5.0$ as solvent B was used. Within the gradient the ACN concentration was linearly increased from $15 \%$ at the beginning, to $20 \%$ at $10 \mathrm{~min}$, to $30 \%$ at $20 \mathrm{~min}$ and finally to $60 \%$ at $25 \mathrm{~min}$. Subsequently, the ACN concentration was lowered to $15 \%$ within $0.1 \mathrm{~min}$ and equilibrated for $10 \mathrm{~min}$ prior to the next injection. To determine the oxytocin concentration by RPHPLC, a calibration curve with three oxytocin standards of known concentration $(0.05,0.1$ and $0.15 \mathrm{mg} / \mathrm{ml}$ oxytocin when analyzing $0.1 \mathrm{mg} / \mathrm{ml}$ OT formulations) determined by UV absorption spectroscopy was prepared. Precision, linearity, limit of detection and limit of quantification of the method were determined according to the ICH guideline (16). 


\section{Size Exclusion HPLC (HP-SEC)}

Size exclusion chromatography was performed using a Superdex peptide 10/300 GL column (GE Healthcare Inc., Brussels, Belgium) on an isocratic HPLC system with a Waters 515 pump, a Waters 717 plus autosampler, a Waters 474 fluorescence detector (Waters, Milford Massachusetts, USA) and a Shimadzu SPD UV/Vis detector (Shimadzu, Tokyo, Japan). Fifty $\mu \mathrm{l}$ were injected and separation was performed at a flow rate of $0.5 \mathrm{ml} / \mathrm{min}$. Peaks were detected by UV absorption at $274 \mathrm{~nm}$, as well as fluorescence detection working with an excitation wavelength of $274 \mathrm{~nm}$ and emission wavelength of $310 \mathrm{~nm}$. Different mobile phases were evaluated for the separation: $50 \mathrm{mM}$ phosphate with $150 \mathrm{mM} \mathrm{NaCl}, \mathrm{pH} 2.0$ or 5.0 , and $30 \% \mathrm{ACN}$ with $70 \% 0.04 \mathrm{M}$ formic acid.

\section{High Resolution Mass Spectrometry (MS)}

All MS experiments were conducted in positive ion mode on a LTQ Orbitrap XL (Thermo Scientific, Bremen, Germany). For MS/MS experiments a normalized collision energy of $35 \%$ was used, the activation time was set to $30 \mathrm{~ms}$ and the activation parameter $q=0.25$. RP-HPLC with UV and MS detection (LCUV-MS) was performed on a Shimadzu Prominence LC-20A HPLC system equipped with an UV/VIS SPD-20A detector (Shimadzu Corporation, Kyoto, Japan) and an Alltima C18 RPcolumn, $5 \mu \mathrm{m}$ particle size, inner diameter of $4.6 \mathrm{~mm}$ and length of $150 \mathrm{~mm}$ (Alltech, Ridderkerk, Netherlands). The HPLC system was coupled to a LTQ Orbitrap mass spectrometer equipped with an Ion Max electrospray ion source (Thermo Scientific, Bremen, Germany). The measurements were performed at a flow rate of $1.0 \mathrm{ml} / \mathrm{min}$, which was split in a 33:67 ratio to the UV detector and the ESI-MS. The injection volume was $20 \mu \mathrm{l}$ for all runs.

Gradient elution was done with $15 \%(v / v) \mathrm{ACN}$ in $50 \mathrm{mM}$ ammonium acetate $\mathrm{pH} 5.0$ as solvent $\mathrm{A}$ and $60 \%(\mathrm{v} / \mathrm{v})$ $\mathrm{ACN}$ in $50 \mathrm{mM}$ ammonium acetate $\mathrm{pH} 5.0$ as solvent $\mathrm{B}$. The ACN concentration was linearly increased from $15 \%$ at $0 \mathrm{~min}$, to $20 \%$ at $10 \mathrm{~min}$, to $30 \%$ at $25 \mathrm{~min}$ and finally to $60 \%$ at $35 \mathrm{~min}$. Subsequently, the ACN concentration was lowered to $15 \%$ within $0.1 \mathrm{~min}$ and equilibrated for $10 \mathrm{~min}$ prior to the next injection.

MS data were collected in data-dependent mode using Xcalibur 2.07 software. The precursor ion scan spectra $(\mathrm{m} / \mathrm{z}$ $300-2,000)$ were acquired with a resolution of 30,000 at $400 \mathrm{~m} / \mathrm{z}$. The most abundant ions were isolated and fragmented in the linear ion trap by collisionally induced dissociation. The resulting fragmentation spectra were recorded with a LTQ detector. The instrument was calibrated externally according to the instructions of the manufacturer. The UV signal at $220 \mathrm{~nm}$ of the HPLC effluent was recorded using LCsolutions software version 1.22 (Shimadzu Corporation, Kyoto, Japan).

Direct infusion MS analysis of fractions from HP-SEC and RP-HPLC analysis was performed using a TriVersa NanoMate robot (Advion BioSystems Inc., Ithaca NY, USA). The precursor ion scan spectra $(\mathrm{m} / \mathrm{z}, 300-2,000)$ were acquired with resolution 100,000 at $400 \mathrm{~m} / \mathrm{z}$ and MS/MS spectra with resolution 30,000. Fractions from RP-HPLC were analyzed as collected and after a reduction step.
Reduction was performed by adding $10 \mathrm{mM}$ dithiothreitol (DTT) in $200 \mathrm{mM}$ ammonium bicarbonate for $10 \mathrm{~min}$ at room temperature. DTT was removed by solid phase extraction using $200 \mu \mathrm{l}$ C18 Stage Tips (Proxeon, Odense, Denmark), wetted with $50 \%$ methanol $/ 0.1 \%$ formic acid. The samples were loaded to the wetted Stage Tips, washed with $0.1 \%$ formic acid and eluted in 50\% methanol/ $/ 0.1 \%$ formic acid.

\section{RESULTS AND DISCUSSION}

\section{Temperature- and pH-dependent Oxytocin Degradation Kinetics}

To study oxytocin degradation a new gradient RP-HPLC method has been set-up based on the European Pharmacopoeia (13) and the isocratic method described by Chaibva and Walker (14). The validation showed that the limit of detection of the developed method for oxytocin was $0.7 \mathrm{ng}$ and the limit of quantification $1.4 \mathrm{ng}$, when using the conditions as described in Materials and Methods. Linearity was given from 0.01 to $1.0 \mathrm{mg} / \mathrm{ml}$ when working with an injection volume of $20 \mu \mathrm{l}$. The relative standard deviation over a concentration range of 0.01 to $0.1 \mathrm{mg} / \mathrm{ml}$ was below $0.5 \%$ for measurements performed during the same day, and the day-to-day variation was less than $1.0 \%$.

The impact of temperature and formulation $\mathrm{pH}$ on oxytocin degradation was studied, by monitoring the decrease in the area of the oxytocin peak (detection $220 \mathrm{~nm}$ ) by RPHPLC with respect to time. Temperatures included in the study were $40,55,70$ and $80^{\circ} \mathrm{C}$ for $0.1 \mathrm{mg} / \mathrm{ml}$ oxytocin formulated in $50 \mathrm{mM}$ phosphate at each of $\mathrm{pH} 2.0,4.5,7.0$ and 9.0. Under these conditions adsorption of oxytocin to the glass vials was not observed and the loss of the oxytocin main peak could be ascribed to degradation. Depending on the formulation $\mathrm{pH}$ different degradation products were observed by RP-HPLC (Fig. 1). Interestingly, the disappearance of the oxytocin peak in RP-HPLC appeared to be (pseudo) first order kinetics at each $\mathrm{pH}$, although various degradation products were formed. The (pseudo) first order kinetics can be seen from the linear relationship of $\ln \mathrm{c} / \mathrm{c}_{0} * 100$ versus time in Fig. 2. The slope of each linear fit (where $r^{2}>0.99$ ) was determined as the observed degradation rate constant $k_{\text {obs }}$ from which the half life $t_{1 / 2}$ in days was calculated (Table I). As expected, the observed $t_{1 / 2}$ decreased with increasing incubation temperature. The oxytocin formulation at $\mathrm{pH} 4.5$ was most stable at all temperatures.

The degradation of oxytocin as a function of concentration was tested at $70^{\circ} \mathrm{C}$ for oxytocin formulated at $0.02 \mathrm{mg} / \mathrm{ml}$, $0.1 \mathrm{mg} / \mathrm{ml}$ and $0.5 \mathrm{mg} / \mathrm{ml}$ over the $\mathrm{pH}$ range of 2.0 to 9.0 . At $\mathrm{pH} 2.0$ the degradation rate constant was clearly concentration independent $\left(\mathrm{k}_{\mathrm{obs}}\right.$ of $\left.0.63 \mathrm{day}^{-1}\right)$ and (pseudo) first order kinetics were found for all concentrations (Fig. 3A). However, for oxytocin formulations of $\mathrm{pH} 4.5,7.0$ and 9.0 the degradation rates increased with the concentration. This was particularly obvious for $\mathrm{pH} 4.5$ formulations (Fig. 3B), for which $\mathrm{k}_{\text {obs }}$ was 0.314 day $^{-1}$ at $0.02 \mathrm{mg} / \mathrm{ml}, 0.391$ day $^{-1}$ at $0.1 \mathrm{mg} / \mathrm{ml}$ and $0.420 \mathrm{day}^{-1}$ at $0.5 \mathrm{mg} / \mathrm{ml}$. For the highest concentration of $0.5 \mathrm{mg} / \mathrm{ml}$ deviation from (pseudo) first order kinetics was evident. This was made more apparent by plotting the residuals of the linear fits (Fig. 3 C,D). A possible explanation for the concentration dependency of the 


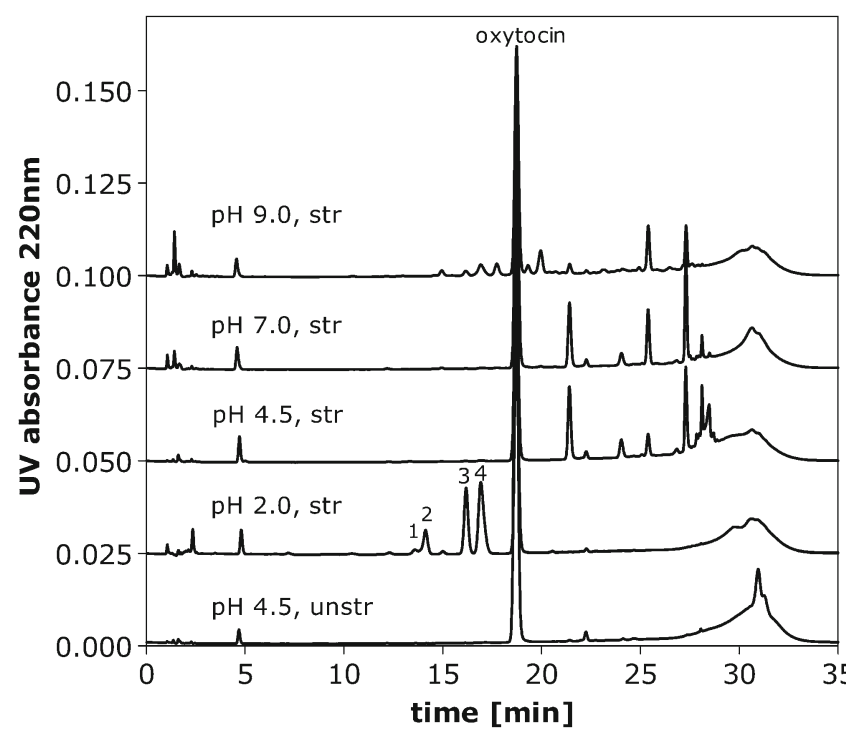

Fig. 1. Example RP-HPLC chromatograms of $0.1 \mathrm{mg} / \mathrm{ml}$ oxytocin standard and stressed formulations in $50 \mathrm{mM}$ phosphate buffer $\mathrm{pH}$ 2.0, 4.5, 7.0 and 9.0 (UV signal at $220 \mathrm{~nm}$ ) analyzed with mobile phase of ACN and phosphate buffer. The peaks eluting before $5 \mathrm{~min}$ are not related to oxytocin, but to the buffer. degradation rate constants is that at higher concentrations aggregation competes with other degradation pathways as the dominant mechanism. Aggregation involves the interaction of at least two molecules and its progression is generally accelerated at higher concentrations. Evidence for the presence of aggregates in heat-stressed formulations is discussed later. Commercial oxytocin formulations maximally contain $10 \mathrm{I} . \mathrm{U} / \mathrm{ml}$, about $0.015 \mathrm{mg} / \mathrm{ml}$ for which aggregation is not likely to occur.

For the formulations containing $0.1 \mathrm{mg} / \mathrm{ml}$ oxytocin we determined whether the relationship between the observed degradation rate constant $\mathrm{k}_{\mathrm{obs}}$ and the temperature obeys the Arrhenius equation (1),

$$
k_{o b s}=A e^{-E a / R T}
$$

where $\mathrm{k}_{\mathrm{obs}}$ is the degradation rate constant in [day ${ }^{-1}$ ], $\mathrm{A}$ is the pre-exponential factor [day ${ }^{-1}$ ], Ea is the activation energy in $\left[\mathrm{J} \mathrm{mol}^{-1}\right], \mathrm{R}$ the molar gas constant $\left(8.314472 \mathrm{~J} \mathrm{~K}^{-1} \mathrm{~mol}^{-1}\right)$ and $\mathrm{T}$ the temperature in $[\mathrm{K}]$. For all formulations studied, the Arrhenius equation provides a good description of oxytocin degradation, as is evident from the linearity $\left(r^{2}>0.99\right)$ of the plots of $\ln k_{\mathrm{obs}}$ versus $1 / \mathrm{T}$ (Fig. 4).
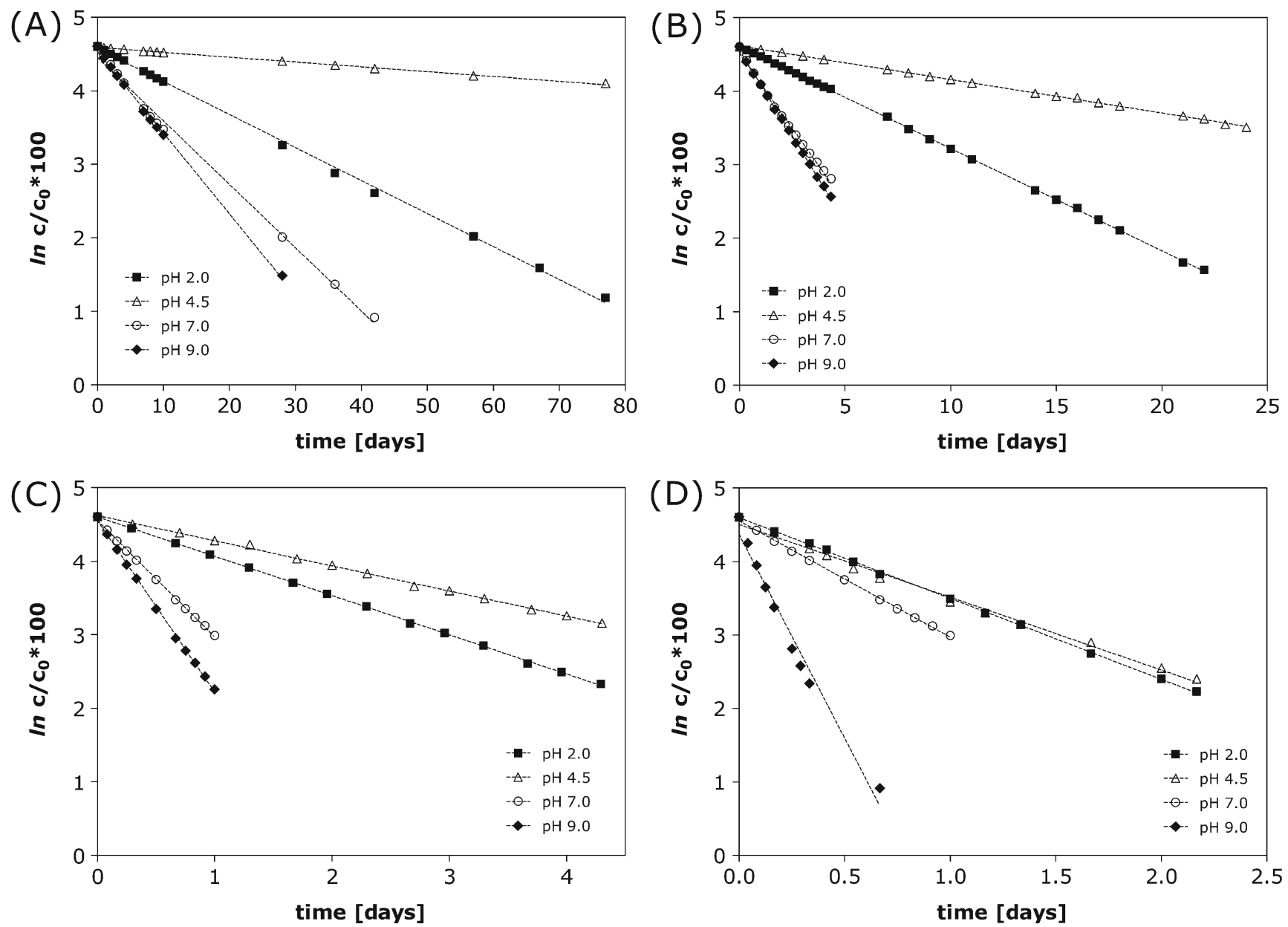

Fig. 2. Degradation of oxytocin over time at $40^{\circ} \mathrm{C}(\mathbf{A}), 55^{\circ} \mathrm{C}(\mathbf{B}), 70^{\circ} \mathrm{C}(\mathbf{C})$ and $80^{\circ} \mathrm{C}(\mathbf{D})$ for formulations with $0.1 \mathrm{mg} / \mathrm{ml} \mathrm{oxytocin} \mathrm{at} \mathrm{pH} 2.0$, 4.5, 7.0 and 9.0 determined by RP-HPLC. Linear fitting (where $r^{2}>0.99$ ) showed the first order kinetics, with the slope of the resulting straight lines representing the degradation rate constant, $k_{\mathrm{obs}}$. 
Table I. Observed Degradation Rate Constants $K_{\text {obs }}(n=3)$ Derived from $l n$-plots of the Loss of the Main Oxytocin Peak in RP-HPLC from $0.1 \mathrm{mg} / \mathrm{ml}$ Oxytocin Formulations Over Time $\left(r^{2}>0.99\right)$ and $t_{1 / 2}$ Calculated as $\ln 2 / \mathrm{k}_{\mathrm{obs}}$

\begin{tabular}{|c|c|c|c|c|c|c|c|c|}
\hline & $\begin{array}{l}k_{\text {obs }} \text { at } 40^{\circ} \mathrm{C} \\
\text { [day }^{-1} \text { ] }\end{array}$ & $\begin{array}{l}t_{1 / 2} \text { at } 40^{\circ} \mathrm{C} \\
\text { [days] }\end{array}$ & $\begin{array}{l}k_{\text {obs }} \text { at } 55^{\circ} \mathrm{C} \\
{\left[\text { day }^{-1} \text { ] }\right.}\end{array}$ & $\begin{array}{l}t_{1 / 2} \text { at } 55^{\circ} \mathrm{C} \\
\text { [days] }\end{array}$ & $\begin{array}{l}k_{\text {obs }} \text { at } 70^{\circ} \mathrm{C} \\
{\left[\text { day }^{-1}\right]}\end{array}$ & $\begin{array}{l}t_{1 / 2} \text { at } 70^{\circ} \mathrm{C} \\
\text { [days] }\end{array}$ & $\begin{array}{l}k_{\text {obs }} \text { at } 80^{\circ} \mathrm{C} \\
\text { day }^{-1} \text { ] }\end{array}$ & $\begin{array}{l}t_{1 / 2} \text { at } 80^{\circ} \mathrm{C} \\
\text { [days] }\end{array}$ \\
\hline$\overline{\mathrm{pH} 2.0}$ & 0.033 & 21.0 & 0.139 & 5.0 & 0.637 & 1.1 & 1.153 & 0.6 \\
\hline pH 4.5 & $0.006^{\mathrm{a}}$ & $115.5^{\mathrm{b}}$ & 0.046 & 15.1 & $0.367^{\mathrm{b}}$ & $1.9^{\mathrm{b}}$ & $1.079^{\mathrm{a}}$ & $0.6^{\mathrm{a}}$ \\
\hline $\mathrm{pH} 7.0$ & 0.080 & 8.7 & 0.438 & 1.6 & 1.606 & 0.4 & $3.594^{\mathrm{a}}$ & $0.2^{\mathrm{a}}$ \\
\hline $\mathrm{pH} 9.0$ & $0.096^{\mathrm{a}}$ & $7.2^{\mathrm{a}}$ & 0.479 & 1.4 & $2.212^{\mathrm{a}}$ & $0.3^{\mathrm{a}}$ & 5.913 & 0.1 \\
\hline
\end{tabular}

The relative standard deviation of three independent degradation experiments was below $5 \%$ if not marked otherwise in the table

${ }^{a}$ Relative standard deviation below $10 \%$

${ }^{b}$ Relative standard deviation below $15 \%$

The activation energy (Ea) for oxytocin degradation was calculated using equation (2).

$$
E a=-m R
$$

where $\mathrm{m}$ is the slope of the Arrhenius plot $[\mathrm{K}]$ and $\mathrm{R}$ the molar gas constant $\left[8.314472 \mathrm{~J} \mathrm{~K}^{-1} \mathrm{~mol}^{-1}\right]$.

For $\mathrm{pH} 4.5$ the highest activation energy of $116.3 \mathrm{~kJ} / \mathrm{mol}$ was calculated. Our finding that oxytocin degradation is slowest at $\mathrm{pH} 4.5$ is in good agreement with the described stability optimum of oxytocin, i.e. in the $\mathrm{pH}$ range between 3 and 5 (5). We compared our results with data on oxytocin degradation available in the WHO report "Stability of injectable oxytocics in tropical climates" (4). Therein, the stability of commercial oxytocin preparations (10 and $5 \mathrm{IU} / \mathrm{ml}$, corresponding to about 15 and $7.5 \mu \mathrm{g} / \mathrm{ml}$, respectively formulated at $\mathrm{pH} 4.0-5.0$ ) was monitored at 4, 21, 30, 40 and $50^{\circ} \mathrm{C}$ for 2 years by RP-HPLC (4). The WHO data also pointed at (pseudo) first order kinetics for oxytocin degradation. Our analysis of these published data yielded activation energies of $128 \pm 3.8 \mathrm{~kJ} / \mathrm{mol}$ for $10 \mathrm{IU} / \mathrm{ml}$ and $116 \pm 5.4 \mathrm{~kJ} / \mathrm{mol}$ for $5 \mathrm{IU} / \mathrm{ml}$ oxytocin, in excellent agreement with the value obtained for
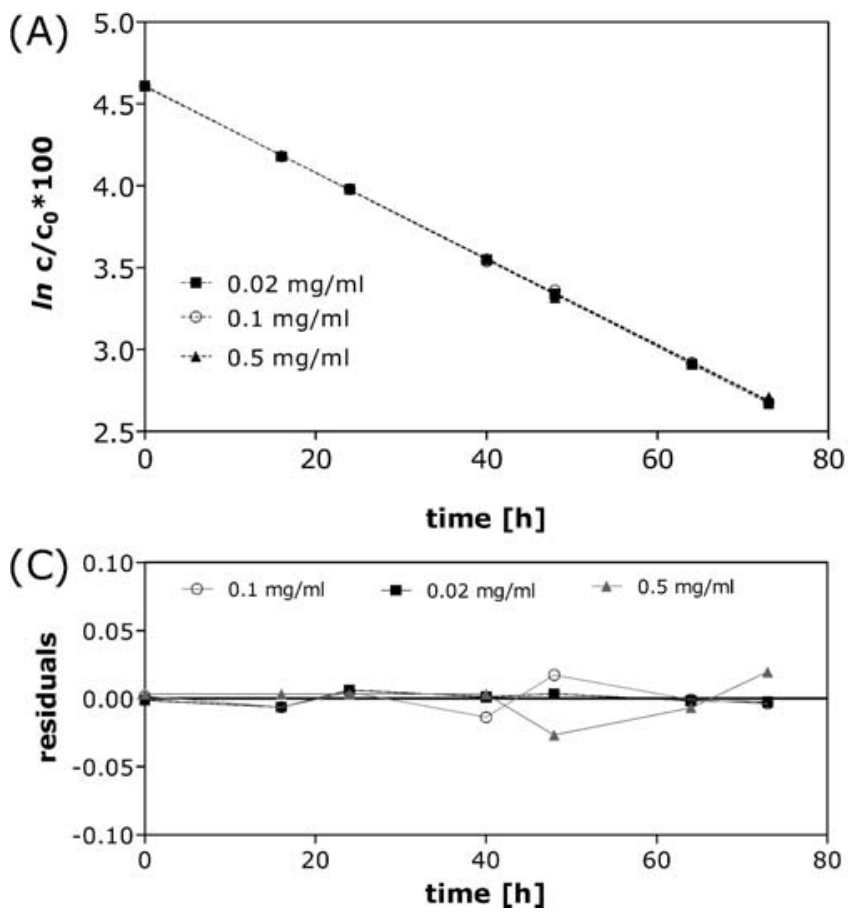

our formulation at $\mathrm{pH} 4.5(116.3 \mathrm{~kJ} / \mathrm{mol})$. The $\mathrm{WHO}$ data indicate that Arrhenius behavior can also be assumed for oxytocin degradation below $40^{\circ} \mathrm{C}$. These findings can facilitate future formulation development, as the Arrhenius behavior will allow extrapolation of the degradation kinetics from accelerated stability testing to lower storage temperatures.

\section{Characterization of Stressed Oxytocin Formulations by UV Absorption and Fluorescence Spectroscopy}

In UV spectroscopy, the formation of aggregates in oxytocin formulations can be monitored by an overall increase in optical density. This was the case for heat stressed oxytocin formulations and was particularly obvious for oxytocin formulated at $\mathrm{pH} 4.5,7.0$ and 9.0. An example is given in Fig. 5A for oxytocin formulated at $\mathrm{pH}$ 4.5. The increase in optical density can be attributed to light scattering because of the presence of large aggregates. In addition, the increase in optical density around 320 to $350 \mathrm{~nm}$ might in part be due to the presence of dityrosine (dimeric) species (17). Dityrosine formation was further confirmed by fluorescence

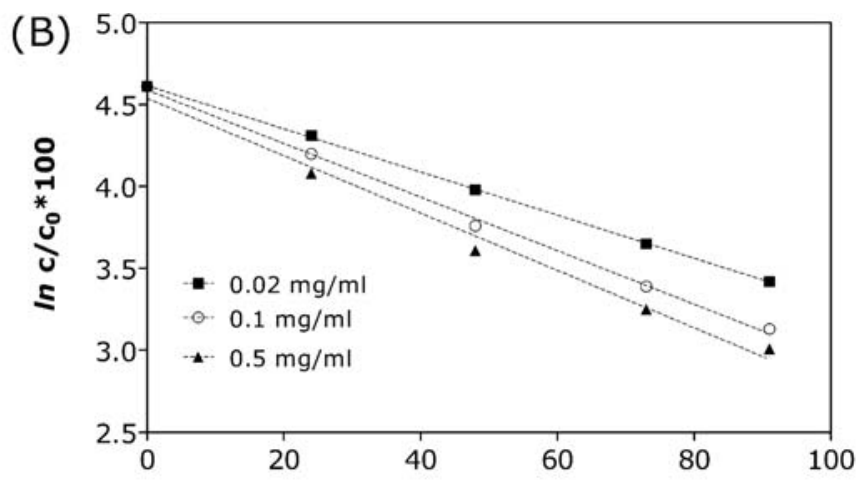

time $[h]$

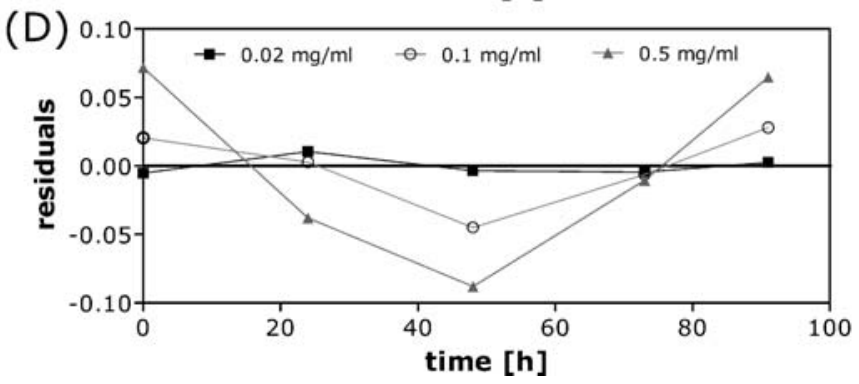

Fig. 3. Concentration dependency of degradation over time at $70^{\circ} \mathrm{C}$ for formulations containing $0.02 \mathrm{mg} / \mathrm{ml}, 0.1 \mathrm{mg} / \mathrm{ml} \mathrm{and} 0.5 \mathrm{mg} / \mathrm{ml}$ oxytocin at $\mathrm{pH} 2.0$ (A) and pH 4.5 (B) determined by RP-HPLC and the residuals of the linear fit for $\mathrm{pH} 2.0$ (C) and $\mathrm{pH} 4.5$ (D). 


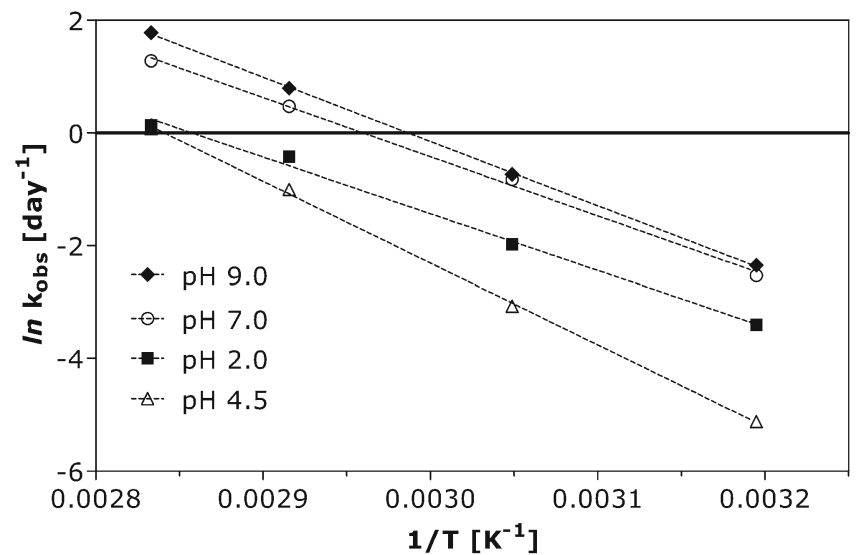

Fig. 4. Arrhenius plot for $0.1 \mathrm{mg} / \mathrm{ml}$ oxytocin formulations at $\mathrm{pH} 2.0$, 4.5, 7.0 and 9.0 calculated from the data of Fig. 2.

spectroscopy. Upon excitation of the stressed $\mathrm{pH} 4.5,7.0$ and 9.0 formulations at $340 \mathrm{~nm}$, fluorescence emission could be measured with a maximum at $410 \mathrm{~nm}$, exemplarily shown for a stressed $\mathrm{pH} 4.5$ formulation (Fig. 5B). The excitation spectrum was also found to vary as a function of $\mathrm{pH}$ (not shown). This is in line with behavior that has previously been reported for dityrosine (17).

\section{Oxytocin Aggregation Analyzed by HP-SEC}

In HP-SEC the $\mathrm{pH}$ of the mobile phase was shown to influence significantly the separation of oxytocin in certain stressed formulations. This was particularly obvious for the stressed pH 2.0 oxytocin formulation (Fig. 6A). When using a mobile phase with a $\mathrm{pH}$ of 5.0 , two shoulders were eluting prior to the monomer peak. RP-HPLC analysis of these fractions could assign those to deamidated oxytocin i.e. they corresponded to the peaks eluting prior to the oxytocin peak in RP-HPLC. This indicates that the separation with a mobile phase of $\mathrm{pH} 5.0$ was not only based on size, but also on interactions of chemically changed oxytocin molecules with the agarose/dextran column material. When lowering the $\mathrm{pH}$ of the mobile phase to 2.0, only one peak was evident by HPSEC for stressed $\mathrm{pH} 2.0$ formulations. Fractionation of the HP-SEC chromatogram and analysis by RP-HPLC proved that monomeric oxytocin and the deamidated species co-elute in HP-SEC under acidic conditions. This behavior might be explained as an effect of electrostatic interactions between the deamidated peptides and the column. At $\mathrm{pH} 2.0$, the carboxylic acids in deamidated oxytocin are protonated and the overall charge of the molecule is zero, whereas at $\mathrm{pH}$ 5.0, the deamidated species will carry a negative charge. For stressed pH 4.5 (Fig. 6B), 7.0 and 9.0 oxytocin formulations and for all unstressed formulations (Fig. 6C) the $\mathrm{pH}$ of the mobile phase had less influence on separation by HP-SEC. Higher molecular weight species were eluting prior to the monomer peak independent of the $\mathrm{pH}$ of the mobile phase, as shown for a stressed oxytocin formulation of $\mathrm{pH} 4.5$ in Fig. 6B. The best separation could be achieved when using a mobile phase consisting of 30\% $\mathrm{ACN}$ and $70 \% 0.04 \mathrm{M}$ formic acid. In order to prove that the separation was based on size, fractions were collected from HP-SEC and analyzed by mass spectrometry. In this way, the main peak eluting at $36 \mathrm{~min}$ in HP-SEC could be attributed to oxytocin monomer $\left([\mathrm{M}+\mathrm{H}]^{+}\right.$, $m / z=1,007.44)$. The HP-SEC UV peak at 26 min was shown to correspond to oxytocin dimers with a mass of $1,950.892 \mathrm{Da}$ (charge $2+, m / z=975.446$ ) (see insert in Fig. 6B). The nature of the dimers is discussed later in this publication.

\section{Mass Spectrometric Identification of Oxytocin Degradation Products}

High resolution ESI-MS and ESI-MS/MS were used to identify the oxytocin degradation products observed by RPHPLC. The analyses were carried out on purified fractions corresponding to each of the major degradation peaks for $\mathrm{pH}$ 2.0, as well as by LC-coupled mass spectrometry for $\mathrm{pH} 4.5,7.0$ and 9.0 formulations. Simulation of the isotope
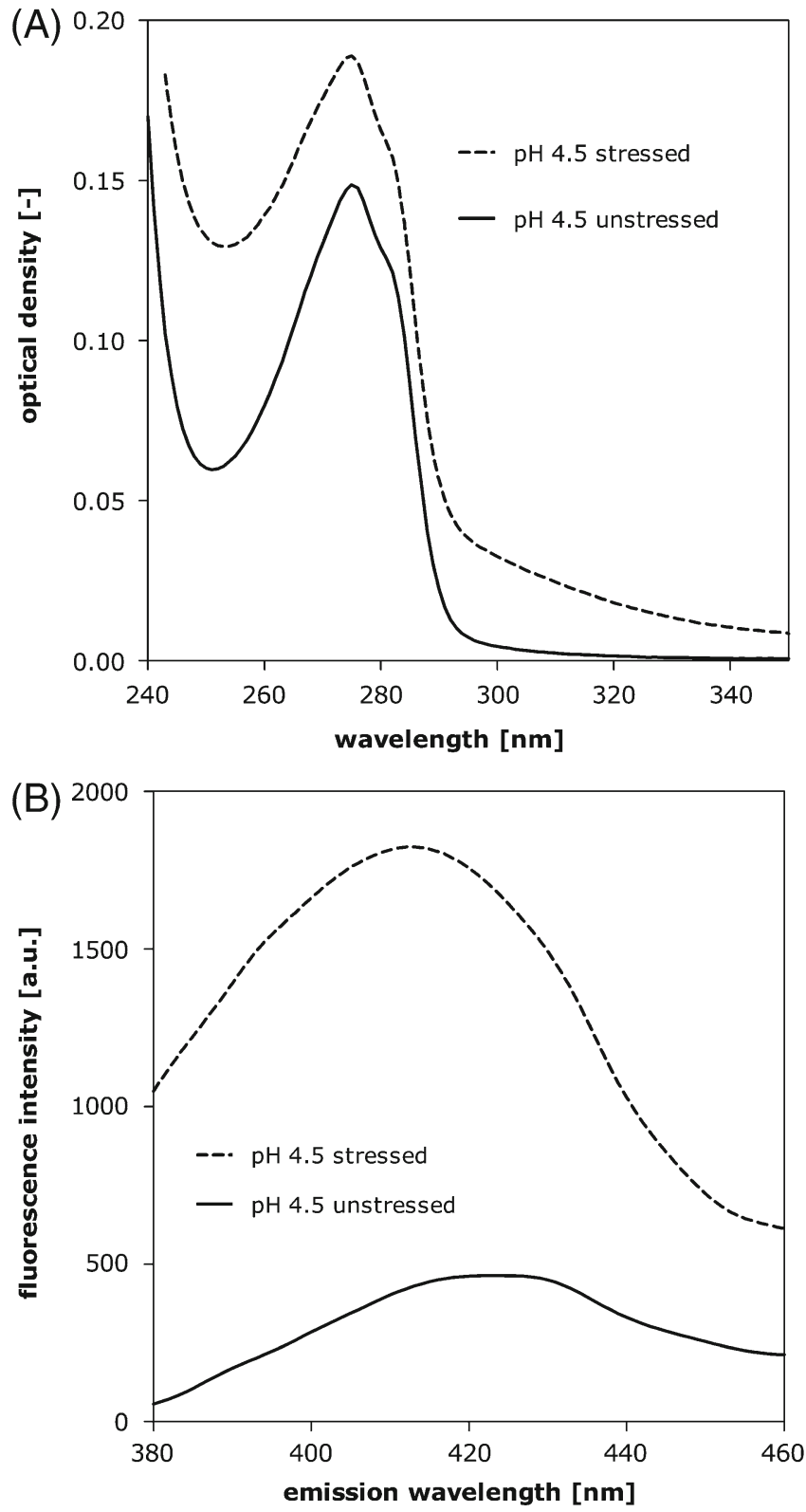

Fig. 5. UV absorption spectrum (A) and fluorescence emissions spectrum after excitation at $340 \mathrm{~nm}($ B $)$ of $0.1 \mathrm{mg} / \mathrm{ml}$ oxytocin $\mathrm{pH} 4.5$ unstressed and stressed for $48 \mathrm{~h}$ at $70^{\circ} \mathrm{C}$. 

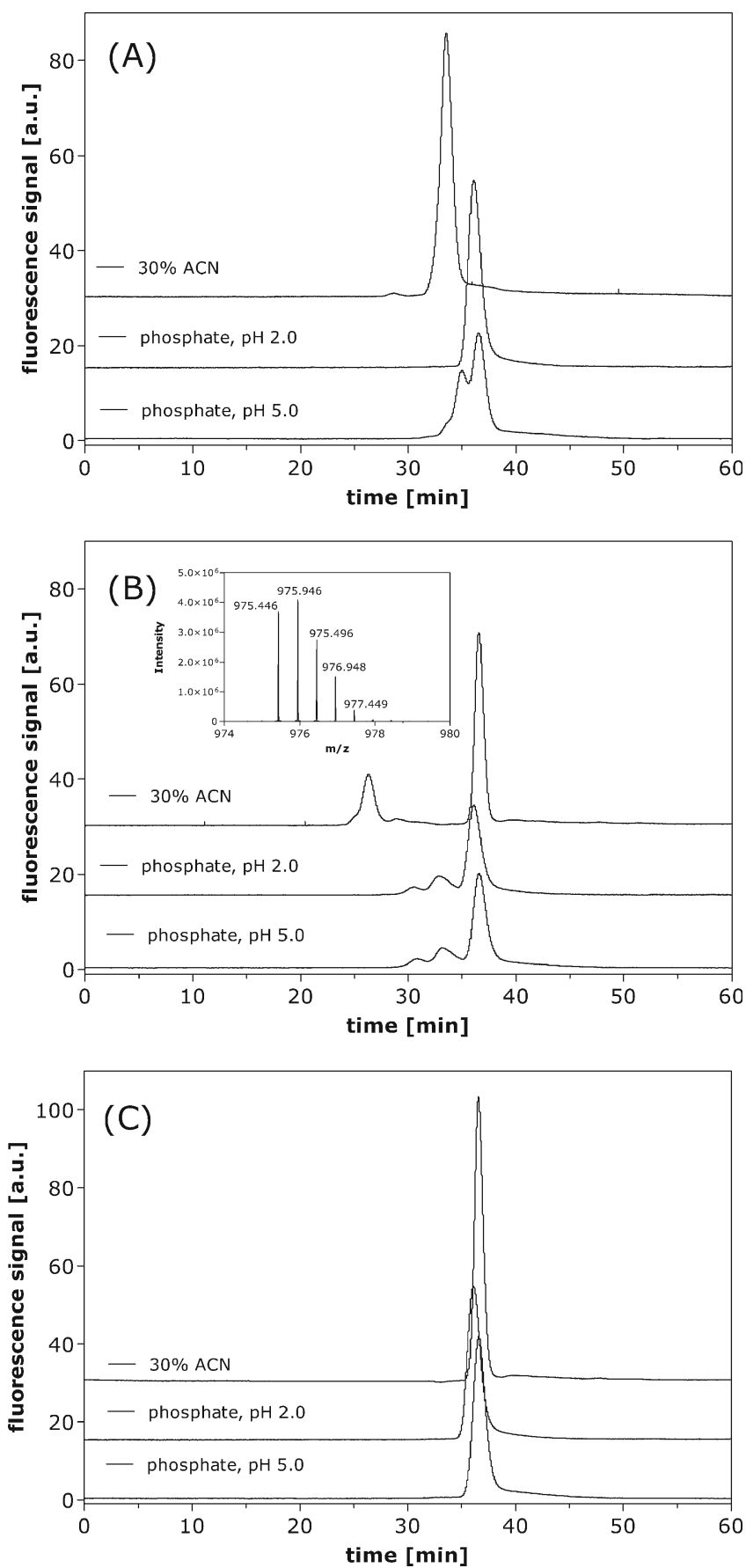

Fig. 6. HP-SEC chromatograms of $0.1 \mathrm{mg} / \mathrm{ml}$ oxytocin formulations at $\mathrm{pH} 2.0$ stressed for $24 \mathrm{~h}$ at $70^{\circ} \mathrm{C}(\mathbf{A})$ and at $\mathrm{pH} 4.5$ for $48 \mathrm{~h}$ at $70^{\circ} \mathrm{C}$ (B) and an unstressed $\mathrm{pH} 4.5$ formulation $(\mathbf{C})$ analyzed with three mobile phases: $50 \mathrm{mM}$ phosphate, $150 \mathrm{mM} \mathrm{NaCl} \mathrm{pH} \mathrm{5.0;} \mathrm{idem} \mathrm{pH} \mathrm{2.0;}$ and $30 \% \mathrm{ACN}, 70 \% 0.04 \mathrm{M}$ formic acid. Insert shows the MS results of the dimer peak measured after fractionation.

patterns and calculation of the expected masses were done to verify our assignments.

A number of different degradation mechanisms are suggested to operate when oxytocin is subjected to thermal stress, mainly depending upon the formulation $\mathrm{pH}$. In the stressed $\mathrm{pH} 2.0$ formulations, the four main degradation peaks eluting before the oxytocin main peak in RP-HPLC (labeled 1-4 in Fig. 1) could be identified as various deamidated oxytocin species. Oxytocin contains three possible deamidation sites: the C-terminal amidated $\mathrm{Gly}^{9}$, as well as $\mathrm{Asn}^{5}$ and $\mathrm{Gln}^{4}$ in the cyclic portion of the molecule. One deamidation reaction ( $\mathrm{R}-\mathrm{CONH}_{2} \rightarrow \mathrm{R}-\mathrm{COOH}$ ) corresponds to a mass difference of $+0.985 \mathrm{Da}$. Given differences in $\mathrm{m} / \mathrm{z}$ relative to the parent ion of +0.985 for peaks 3 and 4 and +1.970 for peaks 1 and 2, the compounds were assigned as mono and bis-deamidated oxytocin, respectively.

In order to be able to elucidate the site(s) of deamidation within oxytocin, the individual RP-HPLC peak fractions were collected. The samples were then reduced with DTT to cleave the disulfide linkage, subjected to solid-phase extraction and analyzed using ESI-MS/MS. By the reduction the oxytocin molecule is linearized enabling a better identification of the fragmentation ions formed in MS/MS. From the fragmentation patterns, it was possible to show that peak 1 corresponded to $\mathrm{Asn}^{5}$ and $\mathrm{Gly}{ }^{9}-\mathrm{NH}_{2}$ deamidation, peak 2 to $\mathrm{Gln}^{4}$ and $\mathrm{Gly}^{9}-\mathrm{NH}_{2}$ deamidation, peak 3 to $\mathrm{Gln}^{4}$ deamidation and peak 4 to deamidation at $\mathrm{Gly}^{9}-\mathrm{NH}_{2}$. A summary of the fragmentation ions and the analysis is shown in Table II.

Fig. 7A shows the rates of formation of each of the deamidated species. Gly ${ }^{9}-\mathrm{NH}_{2}$ deamidates fastest followed by $\mathrm{Gln}^{4}$. Bis-deamidated species also form, whereas $\mathrm{Asn}^{5}$ deamidation is observed only to a minor degree. This might sound contrary to the literature, where asparagine deamidation is generally described as being faster than glutamine deamidation (18). However, within a more complex molecule like a protein or a peptide the conformation can also impact the rate and the likelihood of deamidation $(19,20)$. Structural studies on oxytocin have shown that the hydroxyl group of $\mathrm{Tyr}^{2}$ can form a hydrogen bond with the carboxamide in $\mathrm{Asn}^{5}$ (21,22), by which $\mathrm{Asn}^{5}$ could become less susceptible to deamidation.

The LC-MS and LC-UV traces in Fig. 8 reveal that there is little qualitative difference in terms of the oxytocin degradation products formed upon thermal stress in $\mathrm{pH} 4.5,7.0$ or 9.0 formulations. The only significant difference is the presence of deamidation peaks in $\mathrm{pH} 9.0$ formulations eluting prior to the oxytocin main peak in RP-HPLC. However, deamidation at $\mathrm{pH} 9.0$ is less pronounced as compared to $\mathrm{pH} 2.0$ and generally stops at mono-demidated oxytocin. This is presumably due to the different deamidation mechanisms at low and high $\mathrm{pH}$. Above $\mathrm{pH} 3$ deamidation is thought to proceed via the formation of cyclic imide intermediates for Asn and Gln, as well as base catalyzed hydrolysis, whereas proton-catalyzed hydrolysis dominates below $\mathrm{pH} 3(9,10,23)$. It should be remembered that whilst the degradation profiles were comparable for $\mathrm{pH} 4.5,7.0$ and 9.0, the degradation kinetics differed significantly as discussed earlier. In order to reach about 50\% degradation in RP-HPLC, it was necessary to stress oxytocin formulated at $\mathrm{pH} 4.5$ for $48 \mathrm{~h}$ at $70^{\circ} \mathrm{C}$, whereas at $\mathrm{pH} 9.0$ only $6 \mathrm{~h}$ were needed.

Table III lists the retention times, the $\mathrm{m} / \mathrm{z}$ of the parent ion, the charge and the assignment based on LC-MS for the highest intensity peaks in RP-HPLC identified in heat stressed $\mathrm{pH} 4.5,7.0$ and 9.0 oxytocin formulations (Fig. 8). The main degradation products were found to be tri- and tetrasulfide bridged oxytocin monomers, and sulfur-linked dimers. The nature of these dimers will be discussed further below. Larger aggregates were also observed at the end of the gradient, although they were not well separated under the used RPHPLC conditions. Next to this, a number of minor degradation 
Table II. Identification of Deamidation sites by MS and MS/MS in RP-HPLC Peak Fractions of Heat Stressed Oxytocin Formulations of pH 2.0

\begin{tabular}{|c|c|c|c|c|c|}
\hline \multirow[b]{2}{*}{ Peak } & \multirow[b]{2}{*}{ MS ion $[m / z]$} & \multicolumn{3}{|c|}{ Key fragment ions $[\mathrm{m} / \mathrm{z}]$} & \multirow[b]{2}{*}{ Deamidation site } \\
\hline & & $\mathrm{b}_{6}-\mathrm{NH}_{3}{ }^{\mathrm{a}}$ & $\mathrm{y}_{5}$ ion $^{\mathrm{b}}$ & $\mathrm{b}_{4}$ ion $^{\mathrm{c}}$ & \\
\hline $1(13.7 \mathrm{~min})$ & $1,011.13$ & 709.231 & 504.211 & 508.221 & Asn $^{6}$ and $\mathrm{Gly}^{9}$ \\
\hline $2(14.2 \mathrm{~min})$ & $1,011.40$ & 709.232 & 503.227 & 509.205 & $\mathrm{Gln}^{4}$ and $\mathrm{Gly}^{9}$ \\
\hline $3(16.2 \mathrm{~min})$ & $1,010.44$ & 709.231 & 502.243 & 509.205 & $\mathrm{Gln}^{4}$ \\
\hline $4(16.9 \mathrm{~min})$ & $1,010.44$ & 708.248 & 503.227 & 508.221 & Gly $^{9}$ \\
\hline oxytocin $(18.8 \mathrm{~min})$ & $1,009.46$ & 708.248 & 502.243 & 508.221 & - \\
\hline
\end{tabular}

All samples were reduced with DTT

${ }^{a} \mathrm{~b}_{6}-\mathrm{NH}_{3}$ fragmentation ion contains the amino acids of the oxytocin ring $\mathrm{Cys}^{1}-\mathrm{Tyr}^{2}-\mathrm{Ile}^{3}-\mathrm{Gln}^{4}-\mathrm{Asn}^{5}-\mathrm{Cys}^{6}$ missing $-\mathrm{NH}_{3}$ and has a theoretical mass of 708.25 Da for intact oxytocin

${ }^{b} \mathrm{y}_{5}$-fragmentation ion contains the amino acids $\mathrm{Asn}^{5}$-Cys $\mathrm{CPro}^{7}-\mathrm{Leu}^{8}$-Gly ${ }^{9}$ and has a theoretical mass of 502.24 Da for intact oxytocin

${ }^{c} \mathrm{~b}_{4}$ fragmentation ion contains the amino acids Cys ${ }^{1}-\mathrm{Tyr}^{2}-\mathrm{Ile}^{3}-\mathrm{Gln}^{4}$ and has a theoretical mass of 508.22 Da for intact oxytocin

products were identified, in particular oxidation products either of cystein or tyrosine. However, these contribute less than $1 \%$ to the total area of all RP-HPLC peaks.

High resolution $\mathrm{MS}$ and $\mathrm{MS} / \mathrm{MS}$ analysis provided convincing evidence for the assignment of peaks eluting at 19.3 and 23.3 min as tri- and tetrasulfide-containing degradation products, respectively (Fig. 8). The observed differences in $\mathrm{m} / \mathrm{z}$ of 31.971 and 63.942 correspond to the addition of one and two sulfur atoms, respectively, to oxytocin. MS/MS analysis proved that the sulfur atoms are introduced into the ring portion of the molecule. The peak at $m / z=723.197$ for oxytocin corresponds to $\mathrm{a}_{6}$ fragment including the cyclic portion of oxytocin and $\mathrm{m} / \mathrm{z}$ of 990.430 oxytocin lacking $\mathrm{NH}_{3}$
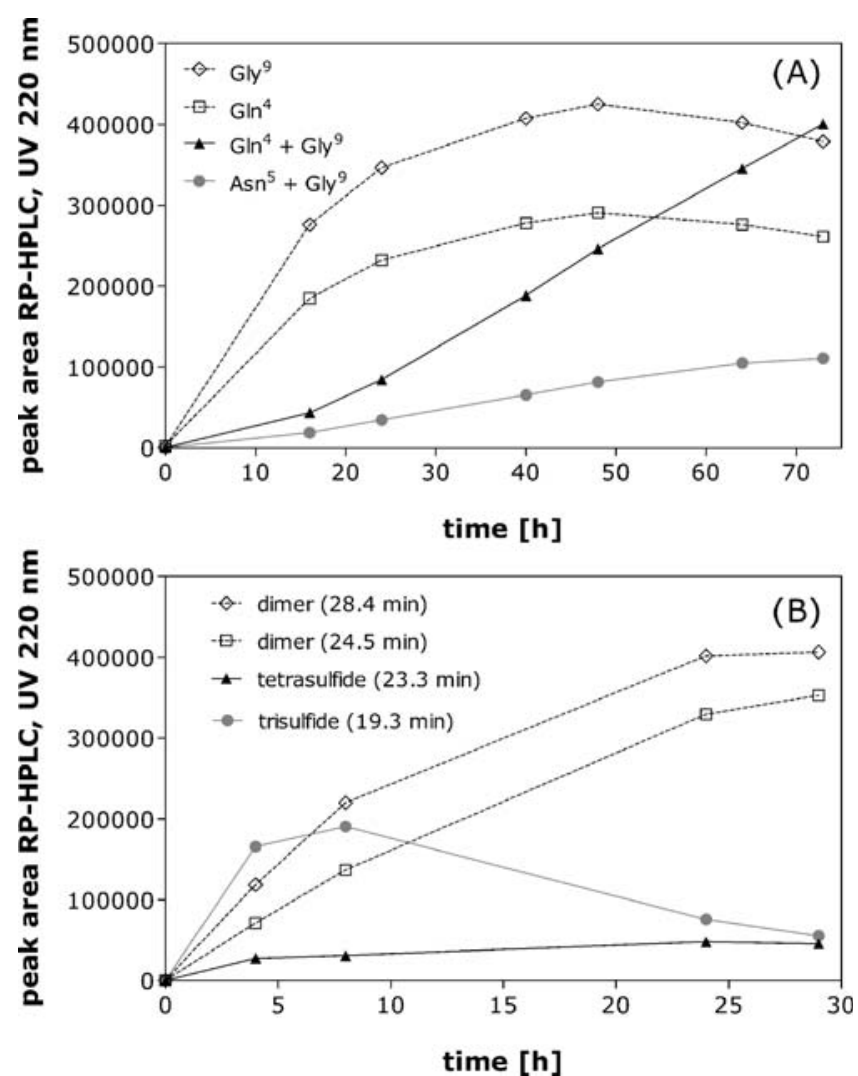

Fig. 7. Formation of different degradation products at $70^{\circ} \mathrm{C}$ measured by RP-HPLC: deamidated species formed at $\mathrm{pH} 2.0(\mathbf{A})$ and trisulfide-, tetrasulfide containing oxytocin and dimers formed at $\mathrm{pH} 7.0(\mathbf{B})$ are shown.
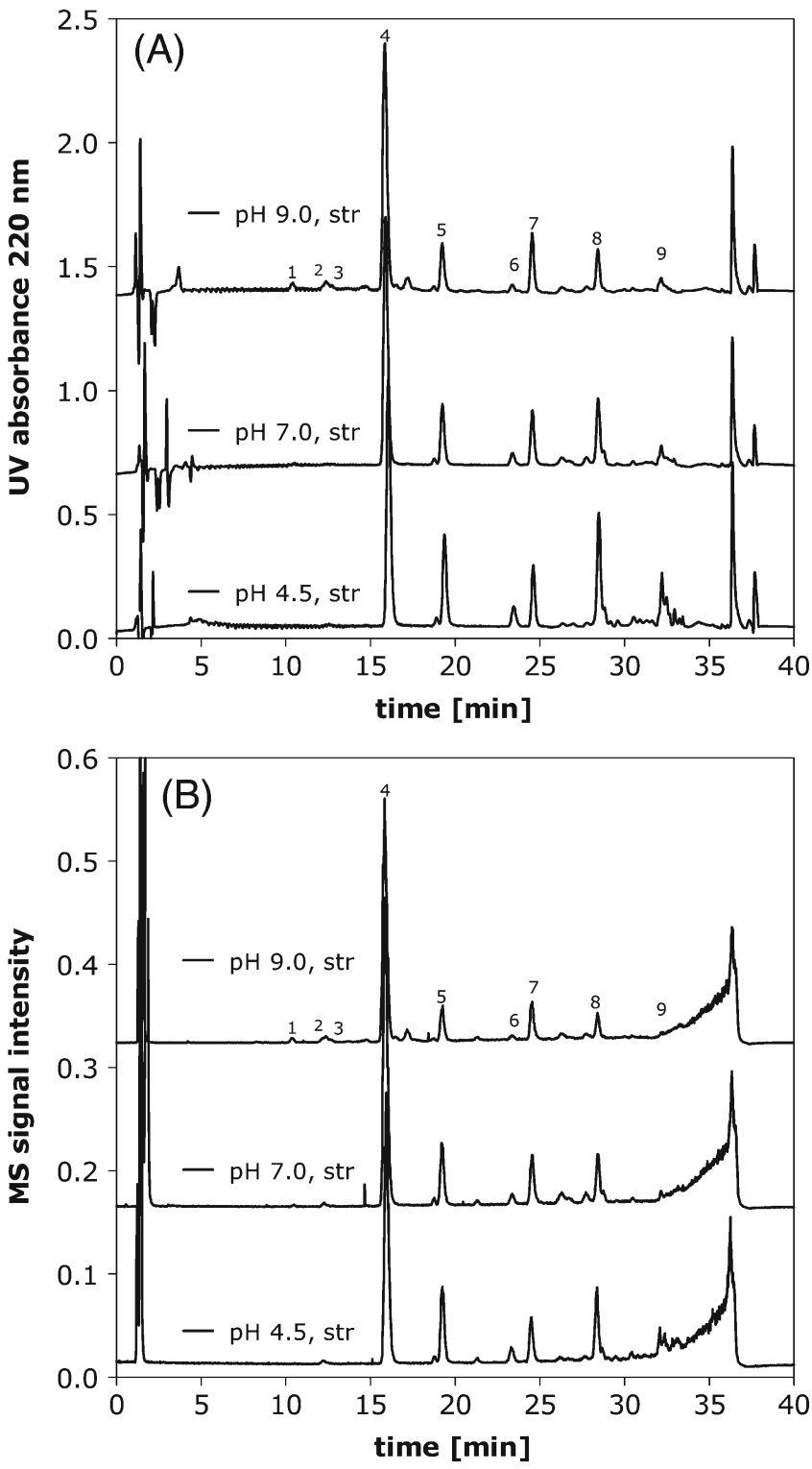

Fig. 8. RP-HPLC with UV (A) and MS (B) detection from heat stressed $\mathrm{pH} 4.5,7.0$ and 9.0 samples used for identification of degradation products. 
Table III. Identification of Oxytocin Degradation Products for pH 4.5, 7.0 and 9.0 Formulations from LC-MS Data Shown in Fig. 8

\begin{tabular}{|c|c|c|c|c|}
\hline Peak number & Retention time [min] & $m / z$ & Charge & Assignment \\
\hline $1^{\mathrm{a}}$ & 10.4 & $1,008.42$ & $1+$ & Mono-deamidation at $\mathrm{Asn}^{6}$ or $\mathrm{Gln}^{4 \mathrm{a}}$ \\
\hline $2^{\mathrm{a}}$ & 12.3 & $1,008.42$ & $1+$ & Mono-deamidation at Gly ${ }^{9 a}$ \\
\hline $3^{\mathrm{a}}$ & 12.6 & $1,008.42$ & $1+$ & Mono-deamidation at $\mathrm{Asn}^{6}$ or $\mathrm{Gln}^{4 *}$ \\
\hline 4 & 15.9 & $1,007.44$ & $1+$ & Oxytocin \\
\hline 5 & 19.3 & $1,039.41$ & $1+$ & Trisulfide \\
\hline 6 & 23.3 & $1,071.38$ & $1+$ & Tetrasulfide \\
\hline 7 & 24.5 & 975.44 & $2+$ & Dimer, bis-deamidated, bis- $\beta$-eliminated \\
\hline 8 & 28.4 & 975.44 & $2+$ & Dimer, bis-deamidated, bis- $\beta$-eliminated \\
\hline 9 & $>30$ & - & multiple & Larger aggregates and others \\
\hline
\end{tabular}

${ }^{a}$ Only present in $\mathrm{pH} 9$ samples, assignment based on MS and MS/MS data

(Fig. 9A). The $\mathrm{b}_{6}$ fragments for the trisulfide (Fig. 9B) and tetrasulfide (Fig. 9C) have a difference in $\mathrm{m} / \mathrm{z}$ relative to this of +31.971 and +63.942 , due to the introduction of one and two sulfur atoms, respectively, into the oxytocin ring.

The identified trisulfide- and tetrasulfide-containing oxytocin degradation products are unusual peptides. Whilst trisulfide formation has been reported in the literature as a thermal decomposition product of the structurally similar peptide salmon calcitonin (24), this is to our knowledge the first reported instance of a tetrasulfide as a degradation product of a peptide or protein. Trisulfides are known to exist in nature as they have been observed in variants of recombinant proteins produced in $E$. coli like in methionyl human growth hormone (25), human growth hormone (26) and a recombinant truncated interleukin-6 mutein (27). Furthermore, trisulfides have been prepared synthetically, e.g. also for oxytocin and deaminooxytocin (28). Tetrasulfides can also be synthesized and are known to be formed as decomposition products following photolysis of cystein $(29,30)$.

The mechanism by which these species form within oxytocin has not yet been fully elucidated. One possible explanation is the mechanism reported by Windisch et al. (1996) for the formation of a trisulfide-containing salmon calcitonin degradation product involving sequential dimerization, $\beta$-elimination and oxidation (24). A radical-based mechanism, as described for cystein (29) may also be postulated. However, this normally requires irradiation with light of an appropriate wavelength.

For heat stressed oxytocin, two dimeric products were evident by mass spectrometry, eluting at 24.5 and $28.4 \mathrm{~min}$. High resolution MS showed the two peaks to be of identical mass, which corresponds to a sulfur-linked dimeric oxytocin species that has been doubly deamidated and which has lost two sulfur atoms through $\beta$-elimination. The measured $\mathrm{m} / \mathrm{z}$ of 975.447 corresponds to the theoretical value of 975.447 calculated for the proposed species. It is difficult to understand why the dimer should be doubly deamidated given that no deamidation has been observed for monomeric oxytocin at either $\mathrm{pH} 4.5$ or 7.0 . It is postulated that $\beta$-elimination may result from an intramolecular reaction, most probably involving the $\mathrm{Asn}^{5}$ side-chain amide. The mechanism of degradation requires further investigation.

Finally, it is interesting to note from Fig. 7B, that the concentration of trisulfide reaches a maximum after about $8 \mathrm{~h}$ at $70^{\circ} \mathrm{C}$ and then decreases, whereas the concentration of all the other degradation products continues to increase. Kinetic analyses such as these can prove valuable in attempting to assign reaction mechanisms. A more thorough mechanistic
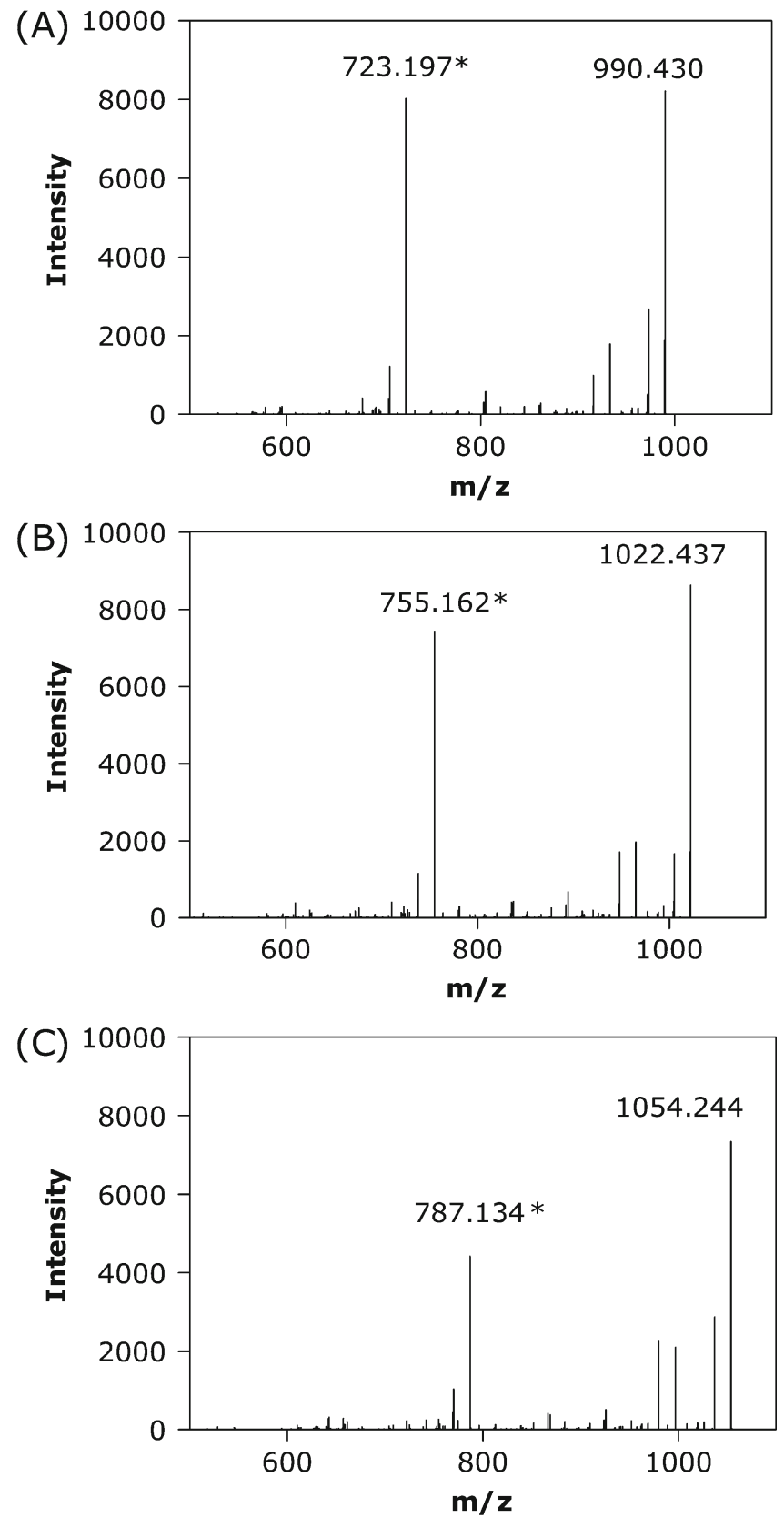

Fig. 9. MS/MS results showing the $b_{6}$-ion (marked with *) from LCMS for the oxytocin main peak, retention time $15.9 \mathrm{~min}, \mathrm{~m} / \mathrm{z} 1,007.44$ (A), trisulfide-containing oxytocin, retention time $19.3 \mathrm{~min}, \mathrm{~m} / \mathrm{z}$ $1,039.42$ (B) and tetrasulfide-containing oxytocin, retention time $23.3 \mathrm{~min}, \mathrm{~m} / \mathrm{z} 1,071.39(\mathbf{C})$. 
investigation into oxytocin degradation is currently under investigation.

\section{CONCLUSIONS}

Within this study, oxytocin degradation and kinetics under conditions relevant for pharmaceutical formulations have been elucidated for the first time. From HP-SEC and RP-HPLC it is obvious that both chemical degradation and aggregation are dominating degradation mechanisms of oxytocin at elevated temperatures. The degradation mechanisms of oxytocin depend on the formulation $\mathrm{pH}$. Various deamidated oxytocin molecules were identified at $\mathrm{pH} 2.0$ and $\mathrm{pH}$ 9.0. At $\mathrm{pH} 4.5,7.0$ and 9.0 the formation of tri- and tetrasulfide-containing monomeric oxytocin, different oxytocin dimers and larger aggregates were identified. Oxytocin degradation in formulations between $\mathrm{pH} 2.0$ and 9.0 follows Arrhenius kinetics, with the $\mathrm{pH} 4.5$ formulation being most stable. This can be beneficial for formulation development as it can enable the prediction of long-term stability at lower temperature from accelerated stress testing.

\section{ACKNOWLEDGEMENTS}

The authors want to thank NV Organon for providing material for the study. This study was performed within the framework of Top Institute Pharma project: number D6202.

Open Access This article is distributed under the terms of the Creative Commons Attribution Noncommercial License which permits any noncommercial use, distribution, and reproduction in any medium, provided the original author(s) and source are credited.

\section{REFERENCES}

1. Meckenzie IZ. Induction of labour at the start of the new millennium. Reproduction 2006;131:989-98. doi:10.1530/ rep.1.00709.

2. van Dongen PWJ, van Roosmalen J, de Boer CN, van Rooy RJ. Oxytocics for the prevention of postpartum haemorrhages, a review. Pharm Weekbl [Sci] 1991;13:238-43. doi:10.1007/BF02015577.

3. Hogerzeil HV, Walker GJA, de Goeje MJ. Stability of injectable oxytocics in tropical climates. WHO report WHO/DAP/93.6 (1993).

4. de Groot N, Hekster YA, Vree TB, Dongen PW. Oxytocin and desamino-oxytocin tablets are not stable under simulated tropical conditions. J Clin Pharm Ther. 1995;20:115-9. doi:10.1111/j.1365-2710.1995.tb00638.x.

5. Nachtmann F, Krummen K, Maxl F, Reimer E. Oxytocin. Analytical profiles of drug substances. Anal Prof Drug Subst. 1981;10:563-600.

6. Neumann DI. Brain oxytocin: A key regulator of emotional and social behaviours in both females and males. J Neuroendocrinol. 2008;20:858-65. doi:10.1111/j.1365-2826.2008.01726.x.

7. Marazziti D, Catena Dell'Osso M. The role of oxytocin in neuropsychiatric disorders. Curr Medical Chem. 2008;15:698704. doi:10.2174/092986708783885291.

8. Walter R, Schwartz IL, Darnell JH, Urry DW. Relation of the conformation of oxytocin to the biology of neurohypophyseal hormones. Proc Natl Acad Sci U S A 1971;68:1355-9. doi:10.1073/pnas.68.6.1355.

9. Manning MC, Patel K, Borchardt RT. Stability of protein pharmaceuticals. Pharm Res. 1989;6:903-11. doi:10.1023/ A:1015929109894.
10. Patel K, Borchardt RT. Chemical pathways of peptide degradation. III. Effect of the primary sequence on the pathway of deamidation of asparaginyl residues in hexapeptides. Pharm Res. 1990;7:787-93. doi:10.1023/A:1015999012852.

11. Houchin ML, Heppert K, Topp EM. Deamidation, acylation and proteolysis of a model peptide in PLGA films. J Control Release. 2006;112:111-9. doi:10.1016/j.jconrel.2006.01.018.

12. Benesch RE, Benesch R. The mechanism of disulfide interchange in acid solution; role of sulfenium ions. J Am Chem Soc. 1958;80:1666-9. doi:10.1021/ja01540a040.

13. European pharmacopoeia 6th edition. Monography oxytocin, pp. 2953-2954 (2009)

14. Chaibva FA, Walker RB. Development and validation of a stability-indicating analytical method for the quantification of oxytocin in pharmaceutical dosage forms. J Pharm Biomed Anal. 2007;43:179-85. doi:10.1016/j.jpba.2006.07.002.

15. Gill SC, von Hippel PH. Calculation of protein extinction coefficients from amino acid sequence data. Anal Biochem. 1989;182:319-326. doi:10.1016/0003-2697(89)90602-7.

16. Q2(R1). Validation of analytical procedures: text and methodology. International conference on harmonisation of technical requirements for registration of pharmaceuticals for human use, November (2005).

17. Malencik DA, Sprouse JF, Swanson CA, Anderson SR. Dityrosine: preparation, isolation and analysis. Anal Biochem. 1996;242:202213. doi:10.1006/abio.1996.0454.

18. Robinson NE, Robinson AB. Molecular clocks: deamidation of asparaginyl and glytaminyl residues in peptides and proteins. Althouss Press, Cave Junction (2004).

19. Xie M, Schowen RL. Secondary structure and protein deamidation. J Pharm Sci. 1999;88:8-13. doi:10.1021/js9802493.

20. Wright TE. Sequence and structure determinants of the nonenzymatic deamidation of asparagine and glutamine residues in peptides. Protein Eng. 1991;4:283-94. doi:10.1093/protein/4.3.283.

21. Kato T, Endo S, Fujiwara T, Nagayama K. Oxytocin solution structure changes upon protonation of the N-terminus in dimethyl sulfoxide. J Biomol NMR. 1993;3:653-73. doi:10.1007/ BF00198370.

22. Turner RJ, Matsoukas JM, Moore GJ. Tyrosinate fluorescence liftetimes for oxytocin and vasopressin in receptor-simulating environments: relationship to biological activity and 1H-NMR data. Biochem Biophys Res Comm. 1990;171:996-1001. doi:10.1016/0006-291X(90)90782-I.

23. Peters B, Trout BL. Asparagine deamidation: pH-dependent mechanism for density fuctional theory. Biochem. 2006;45:53845392. doi:10.1021/bi052438n.

24. Windisch V, DeLuccia F, Duhau L, Herman F, Mencel JJ, Tang S, Vuilhorgne M. Degradation pathways of salmon calcitonin in aqueous solutions. J Pharm Sci. 1997;86:359-64. doi:10.1021/js9602305.

25. Canova-Davis E, Baldonado IP, Chloupek RC, Ling VT, Gehant R, Olson K, Gillece-Castro BL. Confirmation by mass spectrometry of a trisulfide variant in methionyl human growth hormone biosynthesized in Escherichia coli. Anal Chem. 1996;68:4044-51. doi:10.1021/ac9605915.

26. Andersson C, Edlund PO, Gellerfors P, Hansson Y, Holmberg E, Hult C, Johansson S, Kördel J, Lundin R, Mendel-Hartvig IB, Norén B, Wehler T, Widmalm G, Ohman J. Isolation and characterization of a trisulfide variant of recombinant human growth hormone formed during expression in Escherichia coli. Int J Pept Protein Res. 1996;47:311-21.

27. Breton J, Avanzi N, Valsasina B, Sgarella L, La Fiura A, Breme U, Orsini G, Wenisch E, Righetti PG. Detection of traces of a trisulphide derivative in the preparation of a recombinant truncated interleukin-6 mutein. J Chromatograph A 1995;709:13546. doi:10.1016/0021-9673(95)00108-Y.

28. Chen L, Zoulíková I, Jirina Slaninová J, Barany G. Synthesis and pharmacology of novel analogues of oxytocin and deaminooxytocin: directed methods for the construction of disulfide and trisulfide bridges in peptides. J Med Chem. 1997;40:864-76. doi:10.1021/jm9607156.

29. Asquith RS, Hirst L. The photochemical degradation of cystine in aqueous solution in the presence of air. Biochim Biophys Acta 1969; $184: 345-57$

30. Fletcher JC, Robinson A. The occurrence of bis-(2-amino-2carboxyethyl) trisulphide in hydrolysates of wool and other proteins. Biochim J. 1962;87:553-9. 